\section{Evolution of the microbiologi- cal profile of vacuum-packed ricotta salata cheese during shelf-life}

\author{
Daniele Casti, ${ }^{1}$ Christian Scarano, ${ }^{1}$ \\ Carlo Pala, ${ }^{1}$ Francesca Cossu, ${ }^{1}$ \\ Sonia Lamon, ${ }^{1}$ Vincenzo Spanu, ${ }^{1}$ \\ Michela Ibba, ${ }^{1}$ Anna Maria Mocci, ${ }^{1}$ \\ Francesco Tedde, ${ }^{1}$ Gavino Nieddu, ${ }^{2}$ \\ Carlo Spanu, ${ }^{1}$ \\ Enrico Pietro Luigi De Santis' \\ 'Department of Veterinary Medicine, \\ University of Sassari, Sassari; \\ ${ }^{2}$ Cooperativa Allevatori Ovini, Fenosu \\ (OR), Italy
}

\section{Abstract}

Ricotta salata cheese is a salted variety of ricotta traditionally made in Sardinia (Italy) from the whey remaining after the production of Pecorino Romano protected designation of origin or other sheep milk cheeses. Ricotta sala$t a$ cheese is very critical for the possible growth of pathogenic and spoilage microorganisms. Sporadic cases of listeriosis associated with ricotta salata cheese have been reported over recent years. The objective of the present study was to assess the evolution of spoilage and pathogen microorganism of vacuum-packed ricotta salata cheese during the entire product shelf-life. The durability study was conducted on 18 vacuum-packed ricotta salata cheese samples analysed at the beginning of the shelf-life and after 60 and 90 days of refrigerated storage. Pathogens as Listeria monocytogenes and Bacillus cereus were never detected. During shelf-life total bacterial counts ranged between $7.90 \pm 0.64$ and $9.19 \pm 0.58 \mathrm{CFU} \mathrm{g}^{-1}$ on the rind and between $2.95 \pm 0.68$ and $4.27 \pm 1.10 \mathrm{CFU} \mathrm{g}^{-1}$ in the inner paste, while Enterobacteriaceae ranged between $4.22 \pm 0.66$ and $5.30 \pm 0.73 \mathrm{CFU} \mathrm{g}^{-1}$ on the rind and $3.13 \pm 1.80$ and $2.80 \pm 0.88 \mathrm{CFU} \mathrm{g}^{-1}$ in the inner paste. By considering the technology used, the intrinsic properties and the almost total absence of competing microflora, ricotta salata cheese can support the growth of spoilage and pathogen microorganisms originating from the processing environment. The high level of total bacterial counts and Enterobacteriaceae observed both on the rind and in the inner paste suggests contamination of the product from the processing environment. Therefore, a strict implementation of hygiene during processing is essential in order to reduce the load of environmental contaminants that may grow during refrigerated storage.

\section{Introduction}

Ricotta salata cheese or Ricottone or Ricotta Toscanella is a salted variety of ricotta traditionally made in Sardinia (Italy) from the whey remaining after the production of Pecorino Romano protected designation of origin or other sheep milk cheeses. A wide variety of whey cheeses are manufactured from sheep milk in several European countries, especially in the Mediterranean basin: i.e. Mizithra, Anthotyros and Manouri (Greece), Anari (Cyprus), Requesón (Spain), Requeijao (Portugal), Brocciu (France), Urdă (Balkans region), each with its own distinctive technology. In most of the cases these are fresh and soft or semi-soft traditional products made in small-scale operations and sold in local markets. The manufacturing of ricotta salata cheese in Sardinian industrial cheese-making plants follows the traditional batch process (Laore, 2015). The whey is filtered and preheated at $60-70^{\circ} \mathrm{C}$ with the use of a plate heat exchanger. The whey can be added with pasteurised cream or milk to enrich the solid content. The blend is then transferred to large open kettles (1200-1500 L capacity) and heated to temperature above $85^{\circ} \mathrm{C}$ and held for 30 min. After the flocculated protein rises to the surface, clots are collected using perforated ladles and transferred into plastic cylindrical molds lined with cheese cloth. The curd is then pressed to enhance drainage for up to $24 \mathrm{~h}$ and transferred in cold room $\left(10-12^{\circ} \mathrm{C}\right)$ for about 10 days. Salting can be made by adding directly sodium chloride to the whey or to the curd during molding or by drying salt during refrigerated storage or in brine after molding. Ricotta salata cheese is dried until the moisture content is $c a .50 \%$ if intended to be used for grating or of $c a .55-60 \%$ if used as is. After the production process the mean fat and protein content are respectively $28-33 \%$ and $14-23 \%$, the $\mathrm{pH}$ ranges from 6.1 to 6.9 , while the water activity $\left(\mathrm{a}_{\mathrm{W}}\right)$ from 0.940 to 0.970 (Spanu et al., $2012,2013)$. The final product is a firm wheel of $c a .3 \mathrm{~kg}$ weight, which is individually packed in vacuum bags as a whole or after cutting into wedges. Ricotta salata cheese is stored at refrigeration temperature and the attributed shelf-life differs from three weeks up to several months, depending on the food business operators (Spanu et al., 2015b). Ricotta salata cheese is often used in salads or many other dishes sliced, crumbled or grated without further heating. In consideration of its physicochemical properties and the presence of and edible rind, ricotta salata cheese is very critical for the possible growth of pathogenic and spoilage microorganisms. Pathogens of particular concern are those able to grow in ricotta salata cheese at refrigeration temperatures, i.e. Listeria monocytogenes and psychrotrophic
Correspondence: Carlo Spanu, Department of Veterinary Medicine, University of Sassari, via Vienna 2, 07100 Sassari.

Tel: +39.079.229454 - Fax: +39.079 .229458$

E-mail: cspanu@uniss.it

Key words: Whey cheese; Sheep; Composition; Shelf life.

Conflict of interest: the authors declare no potential conflict of interest.

Funding: this work was funded by Programma $d i$ Sviluppo Rurale Sardegna 2007-2013 Misura 124 Cooperazione per lo Sviluppo di Nuovi Prodotti, Processi e Tecnologie nei Settori Agricolo Alimentare $e$ in quello Forestale, project ID: H78F13000050007. The authors are grateful to all the members of the joint dairy industry consortium Associazione Temporanea di Scopo - Aziende Casearie Riunite for their cooperation in the research.

Received for publication: 25 August 2015.

Revision received: 9 October 2015.

Accepted for publication: 9 October 2015

This work is licensed under a Creative Commons Attribution-NonCommercial 4.0 International License (CC BY-NC 4.0).

\section{(C)Copyright D. Casti et al., 2016}

Licensee PAGEPress, Italy

Italian Journal of Food Safety 2016; 5:5501

doi:10.4081/ijfs.2016.5501

Bacillus cereus strains. Outbreaks and sporadic cases of listeriosis associated with ricotta salata cheese have been reported over recent years (RASFF, 2008; CDC, 2012). Evidence that $L$. monocytogenes contamination of ricotta salata cheese origins from the processing environment and that this product supports the growth of the pathogen during refrigerated storage have been documented (Spanu et al., 2012, 2015a; Ibba et al., 2013). Despite the frequent contamination of ricotta salata cheese with $B$. cereus and the recovery of potentially pathogenic strain, no cases of $B$. cereus human illness have been associated with the consumption of ricotta salata cheese (De Santis et al., 2008). The high moisture content, the high $\mathrm{pH}$ and the availability of nutrients considered, such product is very susceptible to microbiological spoilage by Enterobacteriaceae, yeast, moulds and Pseudomonas. The presence of pathogens and contaminants such as $L$. monocytogenes and $B$. cereus has also been observed. However, little research has been conducted to describe the evolution of the microbiological profile of Ricotta salata cheese during the shelf-life (Spanu et al., 2013).

The objective of the present study was to assess and characterise the evolution of 
spoilage and pathogen microorganism of vacuum-packed ricotta salata cheese under refrigerated storage $\left(4 \pm 2^{\circ} \mathrm{C}\right)$ during the entire product shelf-life.

\section{Materials and Methods}

\section{Ricotta salata cheese samples}

The study was conducted on vacuum-packed ricotta salata cheese wheels (Criovac Cook-In HT3000; Sealedair Ltd., St Neots, UK), which were provided by a local cheese-making plant using the whey remaining after the manufacturing of sheep milk cheeses (Table 1). The main steps of the process flow of ricotta salata cheese examined in the present study are summarised in the diagram in Figure 1. A total of 18 samples were randomly selected from 3 different batches (6 ricotta salata cheese for each batch) produced within one month. After a drying period of approximately 10-15 days in cold room, ricotta salata cheese samples were sent to the laboratory. Immediately after their arrival, samples were labelled according to their use for the experiment and stored at refrigeration temperature $\left(4 \pm 1^{\circ} \mathrm{C}\right)$ until analysis was performed.

\section{Experimental design}

The durability study was conducted analysing ricotta salata cheese samples at different time during the shelf-life. Sampling times were: within $24 \mathrm{~h}$ after the arrival of ricotta salata cheese wheels defined as time zero $\left(\mathrm{T}_{0}\right)$, time $60\left(\mathrm{~T}_{60}\right)$ and time $90\left(\mathrm{~T}_{90}\right)$ respectively 60 days and 90 days after the arrival of the samples. In order to avoid temperature abuse during the storage period, the temperature of the cold room was monitored in continuous and recorded daily. Ricotta samples were analysed for the determination of the microbiological profile, physicochemical properties and composition. In Table 1 the number of samples and the analysis performed at each sampling time are reported.

\section{Microbiological profile}

From each ricotta salata cheese sample, $25 \mathrm{~g}$ aliquots of the rind ( $2 \mathrm{~cm}$ in depth) and of the inner paste were aseptically collected. Aliquots were analysed for the enumeration of total viable count (TVC) at $30^{\circ} \mathrm{C}$ (ISO 4833:2003; ISO, 2003), L. monocytogenes (ISO 112901:1996; ISO, 1996), B. cereus (EN/ISO 7932:2004; ISO, 2004b), Enterobacteriaceae (ISO 21528-2; ISO, 2004a), yeasts and moulds (ISO 6611/IDF 94; ISO, 2004c).

\section{Physico-chemical properties and composition}

$\mathrm{pH}$ and $\mathrm{a}_{\mathrm{W}}$ were measured using $\mathrm{pH}$ meter GLP22 (Crison Instruments SA, Barcelona, Spain) and water activity meter Aqualab $4 \mathrm{TE}$ (Decagon, Pullman, WA, USA), respectively. Near infrared transmittance (NIT) compositional analyser (FOSS, Eden Prairie, MN, USA) was used for the determination of centesimal composition which included analysis of moisture, fat, protein, salt and total solids.

Table 1. Number of ricotta salata cheese wheels and analysis performed at each testing time.

Analysis
$\begin{aligned} & \text { Microbiological profile } \\ & \text { Intrinsic properties and composition }\end{aligned}$
$\begin{aligned} & \mathrm{T}_{0}, 0 \text { days after the arrival of the samples (packaging day); } \mathrm{T}_{60}, 60 \text { days after the arrival of the samples; } \mathrm{T}_{90}, 90 \text { days after the arrival of the } \\ & \text { samples. Number of samples per each time refers to the three batches. }\end{aligned}$

Table 2. Mean log microbial counts of ricotta salata cheese units during shelf-life.

\begin{tabular}{llccc} 
Parameters & \multicolumn{2}{l}{ Samples } & $\mathrm{T}_{0}$ & $\mathrm{~T}_{60}$ \\
TVC & Rind & $7.90 \pm 0.64^{\mathrm{a}}(\mathrm{n}=6 / 6)$ & $7.79_{ \pm 0} .21^{\mathrm{a}}(\mathrm{n}=6 / 6)$ & $9.19_{ \pm 0.58^{\mathrm{a}}(\mathrm{n}=6 / 6)}$ \\
& Paste & $2.95 \pm 0.68^{\mathrm{a}}(\mathrm{n}=5 / 6)$ & $4.51 \pm 1.66^{\mathrm{a}}(\mathrm{n}=6 / 6)$ & $4.27 \pm 1.10^{\mathrm{a}}(\mathrm{n}=6 / 6)$ \\
Enterobacteriaceae & Rind & $4.22 \pm 0.66^{\mathrm{b}}(\mathrm{n}=4 / 6)$ & $5.16 \pm 0.59^{\mathrm{ab}}(\mathrm{n}=5 / 6)$ & $5.30^{\mathrm{a}} \pm 0.73(\mathrm{n}=6 / 6)$ \\
& Paste & $\mathrm{nd}$ & $3.13 \pm 1.80^{\mathrm{a}}(\mathrm{n}=3 / 6)$ & $2.80 \pm 0.88^{\mathrm{a}}(\mathrm{n}=2 / 6)$ \\
\hline Yeasts and moulds & Rind & $3.02 \pm 0.36^{\mathrm{b}}(\mathrm{n}=3 / 6)$ & $4.99 \pm 0.81^{\mathrm{a}}(\mathrm{n}=4 / 6)$ & $4.01 \pm 1.03^{\mathrm{ab}}(\mathrm{n}=4 / 6)$ \\
& Paste & $2.00 \pm 0.00^{\mathrm{a}}(\mathrm{n}=2 / 6)$ & $1.67 \pm 0.58^{\mathrm{a}}(\mathrm{n}=3 / 6)$ & $2.30^{\mathrm{a}}(\mathrm{n}=1 / 6)$ \\
\hline
\end{tabular}

$\mathrm{T}_{0}, 0$ days after the arrival of the samples (packaging day); $\mathrm{T}_{60}, 60$ days after the arrival of the samples; $\mathrm{T}_{90}, 90$ days after the arrival of the samples; TVC, total viable counts; nd, not detected (below the detection limit of the method). Values are expressed as mean \pm standard deviation $\left(\log _{10}\right.$ colony forming units $\mathrm{g}^{-1}$ ). Values within brackets indicate the prevalence of positive samples. ${ }^{\mathrm{a}, \mathrm{b}}$ Means in the same row with different superscript letters are significantly different $(\mathrm{P}<0.05)$.

\section{Statistical analysis}

Differences in mean mesophilic bacteria counts $\left(\log _{10} \mathrm{CFU} \mathrm{g^{-1 }}\right)$, intrinsic properties [mean \pm standard deviation (SD)] and composition $(\% \pm \mathrm{SD})$ between sampling times were compared using Fisher's least significant difference (LSD) test. All statistical analyses were performed with R Studio software, version 0.98.1103 (RStudio, Inc., Boston, MA, USA).

\section{Results}

\section{Microbiological profile}

Pathogen microorganisms such as L. monocytogenes and $B$. cereus were always below the detection limit (10 and $100 \log _{10}$ CFU g-1, respectively) both on the rind and in the inner paste. The mean TVC at $\mathrm{T}_{0}$ was $c a .8 \log _{10} \mathrm{CFU}$ $\mathrm{g}^{-1}$ on the rind and $c a .3 \log _{10} \mathrm{CFU} \mathrm{g} \mathrm{g}^{-1}$ in the inner paste, no significant increase during the storage was observed. The mean Enterobacteriaceae count was always greater on the rind as compared to the inner paste, with maximum concentration of $c a .5 \log _{10} \mathrm{CFU}$ $\mathrm{g}^{-1}$ and $3 \log _{10}$ CFU g $^{-1}$ respectively. Yeasts and moulds ranged between 3 and $5 \log \mathrm{CFU} \mathrm{g}^{-1}$ on the rind and were $c a .2 \log \mathrm{CFU} \mathrm{g}^{-1}$ on the inner paste. Table 2 shows the results $\left(\log _{10} \mathrm{CFU} \mathrm{g}{ }^{-1}\right.$; mean \pm SD) of the targeted microbial groups at the different sampling times.

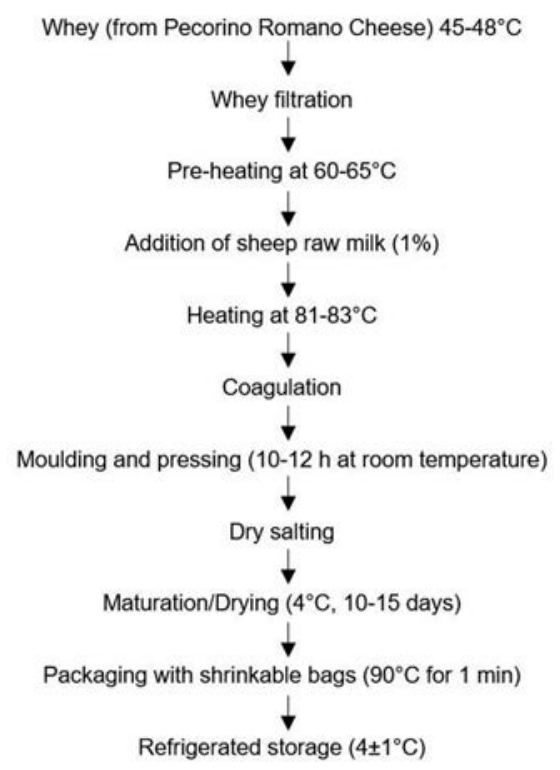

Figure 1. Process flow of the analysed ricotta salata cheese samples. 


\section{Intrinsic properties and composition}

The $\mathrm{pH}$ of ricotta salata cheese during refrigerated storage under vacuum packing decreased from an initial level $\left(\mathrm{T}_{0}\right)$ of $6.54 \pm 0.05$ to a final level $\left(\mathrm{T}_{90}\right)$ of $5.68 \pm 0.16$ $(\mathrm{P}<0.05)$. The $\mathrm{a}_{\mathrm{w}}$ was stable for the entire duration of the study at level between $0.97 \pm 0.01$ and $0.98 \pm 0.01 \quad(P>0.05)$. Minor changes in composition (moisture, fat, proteins, salt and total solids) were observed during storage. Table 3 shows the intrinsic properties (mean $\pm \mathrm{SD}$ ) and composition $(\% \pm \mathrm{SD})$ evolution during storage $\left(\mathrm{T}_{0}, \mathrm{~T}_{60}, \mathrm{~T}_{90}\right)$ of ricotta salata cheese wheels.

\section{Discussion}

The durability of ricotta salata cheese defined by food business operator is generally of several months under refrigerated storage. The shelf-life of ricotta salata cheese depends upon a number of interacting factors other than storage temperature such as packaging conditions, product composition, presence of preservatives and competitive microflora. The combination of production technology (whey heating which inactivates natural microflora and absence of starter cultures), intrinsic properties (high $\mathrm{pH}$ and elevated $\mathrm{a}_{\mathrm{W}}$ ), determine the ability of the product to support the growth of pathogen and spoilage microorganisms. The origin of contamination can be from raw materials or from the environment and differs from one microorganism to another (Almeida et al., 2013). The production of ricotta salata cheese, especially in the traditional batch manufacturing system, includes manual manipulation of the curd after floating, the exposition to environmental contamination from several food contact surfaces (drainage tables, plastic moulds, pressing equipment, drying shelves) and non-food contact surfaces (floors, drains, walls and ceiling).

Table 3. Intrinsic properties and composition evolution during storage of ricotta salata cheese wheels.

\begin{tabular}{lccc} 
Parameters & $\mathrm{T}_{0}$ & $\mathrm{~T}_{60}$ & $\mathrm{~T}_{90}$ \\
$\mathrm{pH}$ & $6.54 \pm 0.03^{\mathrm{a}}$ & $6.04 \pm 0.14^{\mathrm{b}}$ & $5.68 \pm 0.18^{\mathrm{c}}$ \\
$\mathrm{a}_{\mathrm{W}}$ & $0.973 \pm 0.005^{\mathrm{a}}$ & $0.977 \pm 0.008^{\mathrm{a}}$ & $0.978 \pm 0.005^{\mathrm{a}}$ \\
\hline Moisture (\%) & $57.9 \pm 1.85^{\mathrm{a}}$ & $56.3 \pm 0.88^{\mathrm{a}}$ & $57.2 \pm 1.81^{\mathrm{a}}$ \\
Total solids (\%) & $42.13 \pm 1.84^{\mathrm{a}}$ & $44.65 \pm 3.75^{\mathrm{a}}$ & $43.33 \pm 5.01^{\mathrm{a}}$ \\
\hline Fat (\%) & $19.55 \pm 2.08^{\mathrm{a}}$ & $21.24 \pm 0.94^{\mathrm{a}}$ & $20.08 \pm 1.74^{\mathrm{a}}$ \\
Protein (\%) & $14.84 \pm 0.81^{\mathrm{a}}$ & $15.18 \pm 0.52^{\mathrm{a}}$ & $15.17 \pm 1.03^{\mathrm{a}}$ \\
\hline Salt (\%) & $3.42 \pm 0.24^{\mathrm{a}}$ & $3.10 \pm 0.34^{\mathrm{a}}$ & $3.38 \pm 0.34^{\mathrm{a}}$
\end{tabular}

$\mathrm{T}_{0}, 0$ days after the arrival of the samples (packaging day); $\mathrm{T}_{60}, 60$ days after the arrival of the samples; $\mathrm{T}_{90}, 90$ days after the arrival of the samples. Values are expressed as mean or \% (where specified) \pm standard deviation. ${ }^{a-c}$ Means in the same row with different superscript letters are significantly different $(\mathrm{P}<0.05)$.

Contaminants may reach the product by means of aerosol, condenses, dripping or inappropriate practices of operators (Wiedmann, 2003). The batch production of ricotta salata cheese is an open system which exposes the product to environmental contamination. The enumeration of total viable count showed a total bacterial load ca. 4 log greater on the rind as compared to the inner paste. This is the result of the exposition of the rind to the processing environment. This is confirmed by the high contamination with Enterobacteriaceae especially on the rind. Although no microbiological criteria is defined by Regulation (EC) No 2073/205 (European Commission, 2005) for Enterobacteriaceae in whey cheeses that undergone heat treatment, the presence of these important indicator microorganisms reveals that in the cheese-making plants good hygienic and good manufacturing practices should be improved. In particular, the presence of Enterobacteriaceae in the inner paste indicates poor hygienic conditions in the phase of ricotta salata cheese molding. This is a very critical step in ricotta production, where manual manipulation can transfer contaminants from the processing environment into the inner product. With reference to pathogenic microorganisms it is demonstrated that $L$. monocytogenes contamination origins from the processing environment. Food contact and non-food contact surfaces represent the main vehicles of contamination, mainly due to manipulation of the product after the production process. This explains the frequent recovery of $L$. monocytogenes on ricotta salata cheese rind (Spanu et al., 2012, 2015a; Ibba et al., 2013). Contamination of the inner paste is a rare finding and is generally associated with poor hygienic procedures during manual molding (Spanu et al., 2015b). Previous studies reported a prevalence of contamination ranging from $0.0 \%$ up to $30.0 \%$ of the samples (Pilo et al., 2007; Spanu et al., 2015a). In the present study $L$. monocytogenes was below the detection limit $\left(<0.04 \mathrm{CFU} \mathrm{g}^{-1}\right)$ both on the rind and

\section{Conclusions}

The batch production system adopted in Sardinian traditional sheep ricotta salata cheese production and the presence of manual manipulation make this product particularly exposed to environmental contamination. In addition, the absence of a competitive microflora, the richness in nutrient and the intrinsic properties are favourable conditions for growth of spoilage and pathogen microorganisms. The strategies for the control of environmental contaminants are based on their prevention through the strict implementation of hygienic conditions during production process. Superficial contamination of the products can be reduced by the adoption of postlethality treatment (i.e. heat treatment) in vacuum-packed product, allowing to extend ricotta 
salata cheese shelf-life. As far as control of contaminants originating from raw ingredients are concerned, which are not eliminated during processing (say sporeformers), it relies upon prevention of their growth through the maintenance of an unbroken chill chain during the storage.

\section{References}

Almeida G, Magalhães R, Carneiro L, Santos I, Silva J, Ferreira V, Hogg T, Teixeira P, 2013. Foci of contamination of Listeria monocytogenes in different cheese processing plants. Int J Food Microbiol 167:303-9.

Carpentier B, Cerf 0, 2011. Persistence of Listeria monocytogenes in food industry equipment and premises. Int $\mathrm{J}$ Food Microbiol 145:1-8.

CDC, 2012. Multistate outbreak of listeriosis linked to imported Frescolina Martebrand ricotta salata cheese (final update). Centers for Disease Control and Prevention, Atlanta, GA, USA. Available from: http://www.cdc.gov/listeria/outbreaks/cheese-09-12/

De Santis EPL, Foddai A, Virdis S, Marongiu P, Pilo AL, Scarano C, 2008. Toxin gene pattern in Bacillus cereus group strains isolated from sheep ricotta cheese. Vet Res Commun 32:323-6.

EFSA, 2015. The European Union summary report on trends and sources of zoonoses, zoonotic agents and food-borne outbreaks in 2013. EFSA J 13:3991.

European Commission, 2005. Commission Regulation of 15 November 2005 on microbiological criteria for foodstuffs, 2073/2005/EC. In: Official Journal, L 338/1, 22/12/2005.

Griffiths MW, Phillips JD, 1990. Incidence, source and some properties of psychrotrophic Bacillus found in raw and pasteurised milk. Int J Dairy Technol 43:62-6.

Ibba M, Cossu F, Spanu V, Virdis S, Spanu C, Scarano C, De Santis EPL, 2013. Listeria monocytogenes contamination in dairy plants: evaluation of Listeria monocyto- genes environmental contamination in two cheese-making plants using sheeps milk. Ital J Food Safety 2:e31.

Heyndrickx M, 2011. The importance of endospore-forming bacteria originating from soil for contamination of industrial food processing. Appl Environ Soil Sci 2011:561975.

ICMSF, 1996. International commission on microbiological specification for foods. Microorganisms in foods. 1st ed. Clays Ltd., Suffolk, UK.

ISO, 1996. Microbiology of food and animal feeding stuffs-horizontal method for the detection and enumeration of Listeria monocytogenes. Part 1: detection method. ISO Norm 11290-1. International Standardization Organization ed., Geneva, Switzerland.

ISO, 2003. Microbiology of food and animal feeding stuffs. Horizontal method for the enumeration of microorganisms: colony count technique at $30^{\circ} \mathrm{C}$. ISO Norm 4833 . International Standardization Organization ed., Geneva, Switzerland.

ISO, 2004a. Microbiology of food and animal feeding stuffs. Horizontal methods for the detection and enumeration of Enterobacteriaceae. Part 2: colony-count method. ISO Norm 21528-1. International Standardization Organization ed., Geneva, Switzerland.

ISO, 2004b. Microbiology of food and animal feeding stuffs. Horizontal method for the enumeration of presumptive Bacillus cereus and colony-count technique at $30^{\circ} \mathrm{C}$. ISO Norm 7932. International Standardization Organization ed., Geneva, Switzerland.

ISO, 2004c. Milk and milk products. Enumeration of colony-forming units of yeasts and/or moulds. Colony-count technique at $25^{\circ} \mathrm{C}$. ISO Norm 6611:2004 (IDF 94:2004). International Standardization Organization ed., Geneva, Switzerland.

Laore, 2015. L'agroalimentare a marchio di qualità. Formaggi. Laore-Agenzia regionale per lo sviluppo in agricoltura, Cagliari, Italy. Available from: http://www.sardegnaagricoltura.it/documenti/14_43_201410 06144130.pdf

Pilo AL, Marongiu P, Corgiolu G, Virdis S, Scarano C, De Santis EPL, 2007. Listeria monocytogenes contamination sources in sheep cheese processing plants and strains virulence genes typing. In: Proceeding of the 5th IDF International Symposium on the Challenge to Sheep and Goats Milk Sectors, Alghero, Italy.

RASFF, 2008. The Rapid Alert System for Food and Feed annual report. Available from: http://ec.europa.eu/food/safety/rasff/docs/r asff_annual_report_2008_en.pdf

Scheldeman P, Herman L, Foster L, Heyndrickx M, 2006. Bacillus sporothermodurans and other highly heat-resistant spore formers in milk. J Appl Microbiol 101:542-55.

Spanu C, Scarano C, Ibba M, Spanu V, De Santis EPL, 2015a. Occurrence and traceability of Listeria monocytogenes strains isolated from sheep's milk cheese making plants environment. Food Control 318:32547.

Spanu C, Scarano C, Spanu V, Pala C, Di Salvo R, Piga C, Buschettu L, Casti D, Lamon S, Cossu F, Ibba M, De Santis EPL, 2015b. Comparison of post-lethality thermal treatment conditions on the reduction of Listeria monocytogenes and sensory properties of vacuum packed ricotta salata cheese. Food Control 740:747-50.

Spanu C, Scarano C, Spanu V, Penna C, Virdis S, De Santis EPL, 2012. Listeria monocytogenes growth potential in Ricotta salata cheese. Int Dairy J 120:122-24.

Spanu C, Spanu V, Pala C, Virdis S, Scarano C, De Santis EPL, 2013. Evaluation of a postlethality treatment against Listeria monocytogenes on Ricotta salata cheese. Food Control 30:200-5.

Tompkin RB, 2002. Control of Listeria in the food-processing environment. J Food Protect 65:709-23.

Wiedmann M, 2003. ADSA Foundation Scholar Award. An integrated science-based approach to dairy food safety: Listeria monocytogenes as a model system. J Dairy Sci 86:1865-75. 